\title{
SOME AGARICS IN THE SUBALPINE AND ALPINE BELTS OF THE ALTAJ (RUSSIA) AND TYAN'-SHAN' (KYRGYZSTAN) MOUNTAINS
}

\section{K. Kalamees}

Kalamees, K. 2008. Some agarics in the subalpine and alpine belts of the Altaj (Russia) and Tyan'-Shan' (Kyrgyzstan) mountains. - Sommerfeltia 31: 133-138. ISBN 82-7420-045-4. ISSN 0800-6865.

Systematic and ecological data are presented on some agarics recorded in the subalpine and alpine belts of the Altaj (Russia) and Tyan'-Shan' (Kyrgyzstan) mountains, collected in the years 1969 and 1971. The treated species are: Cortinarius subtorvus Lamoure, Inocybe giacomi Favre, Hemimycena phlomisii Kalamees (spec. nov.), Melanoleuca cognata (Fr.) Konrad \& Maubl. s.l., Rickenella fibula (Bull. : Fr.) Raithelhub., Rugosomyces caucasicus (Singer) Kalamees, Lactarius brunneoviolaceus M.P. Christ. and L. dryadophilus Kühner.

Kuulo Kalamees, University of Tartu, Institute of Botany and Ecology, 40 Lai St, 51005 Tartu, Estonia, and Estonian University of Life Sciences, Institute of Agricultural and Environmental Sciences, 181 RiiaSt, 51014 Tartu, Estonia.kuulo@zbi.ee

\section{INTRODUCTION}

Few mycological investigations have been performed in Central Asian mountains (cf. Singer 1943, Eljchibayev 1969), and for large areas, such as the subalpine and alpine belts of Altaj (Russia) and Tyan'-Shan' (Kyrgyzstan), so far entirely lacking. The objective of this work was to study the taxonomy and ecology of agarics collected from two Central Asian sites.

\section{MATERIALS AND METHODS}

The material presented below is collected in two localities: 1) the Altaj Mt. (Russia, Altaj Terr., GornoAltajsk Prov., Ust'-Koksa Distr., range of Katun, between the rivers of Kochurla and Akkem, near the pass of Karatyurek, 1800-2800 m a.s.l., with Betula rotundifolia, Salix spp., Juniperus spp., Dryas oxyodontha, Polygonum viviparum, single Larix sibirica and Pinus sibirica, in July and August 1969) by K. Kalamees, A. Kollom, M. Laane, M. Vaasma and E. Ader (E. Vaheri), and 2) the Tyan'-Shan' Mt. (Kyrgyzstan, Issyk-Kul'sk Prov., range of Terskej Alatoo, Pokrovka, near the river of Karabatkak, 3100-3200 m a.s.1., with Salix spp., Berberis hispida, Juniperus turkestanica, J. pseudosabina, Phlomis oreophila, single Picea schrenkiana and Abies semenovii, on August 1971) by K. Kalamees and A. Kollom, collecting took place in the subalpine and alpine belts. In the Altaj Mt. the timberline is 
located at the altitude of c. $2000 \mathrm{~m}$ a.s.1., in Tyan'-Shan' Mt. - c. $3000 \mathrm{~m}$ a.s.1.

All the species presented were identified by K. Kalamees. Macroscopic descriptions are based on personal observations of fresh material. Microscopic investigations were carried out using a light microscope SWIFT M4000-D at magnification $\times 1000$ in 3\% KOH solution. Spore sizes are based on 20 measured spores from a gill. The size of $10 \%$ of the spores measured is given in brackets.

For transliterating Russian geographical names the handbook of Butcher (1992) was used.

\section{RESULTS AND DISCUSSION}

Data on taxonomy and ecology of 8 species of agarics new for the regions investigated are presented. A new species, Hemimycena phlomisii Kalamees, is described.

\section{Commented descriptions of species}

\section{Cortinarius (Telamonia) subtorvus Lamoure}

Description. Fruit body thick fleshy, with greyish white abundant cortina. Cap weakly hygrophanous, purplish grey-brown, micaceous-fibrillose from veil when young, convex-umbonate, up to $4 \mathrm{~cm}$. Gills lilac when young. Stem lilac at apex, silky-white fibrillose from veil in the lower part, short and fleshy, bulbose at base, up to $3 \times 1$ (base up to 1.5 ) $\mathrm{cm}$. Smell of radish. Spores weakly verrucose, $(8-) 8.5-9.5 \times(4.5-) 4.8-5.5 \mu \mathrm{m}, \mathrm{Q}=1.6-1.8$.

Habitat, distribution and specimen examined. Kyrgyzstan, Tyan'-Shan' Mt., Karabatkak, in subalpine shrubs, $3100 \mathrm{~m}$ a.s.1., August 2., 1971 (TAA 79673); rare.

Note on distribution. Common arctic-alpine species in Eurasia and North America, also in Svalbard and Greenland (Gulden et al. 1985; Brandrud et al. 1994; Karatygin et al. 1999; Horak 2005).

\section{Hemimycena phlomisii Kalamees, spec. nov.}

Fig. 1.

Pileus 0.2-0.5 cm, convexus, postremo centro depressus, hygrophanus, margine striata, albus vel cremeoalbidus, in sicco subpruinosus. Lamellae distantes, decurrentes, albidae. Stipes 1-1.5 × $0.1 \mathrm{~cm}$, albidus, pruinoso-pilosellus. Sporae (6-)7-8 $\times$ 4-5 $\mu \mathrm{m}$, lato ellipticae, glabrae, non amyloideae. Cheilo- et pleurocystidia nulla. Caulocystidia 35-130 × 5-6.5 × 2-2.5 $\mu \mathrm{m}$, anguste conici, tenuiter tunicata, interdum septata. Basidia 25-50 × 5-7 $\mu \mathrm{m}$, 4-sporigera. In pratis subalpinis, ad Phlomis oreophila, saepe.

Holotype: Kyrgyzstan, Tyan'-Shan' Mt., Terskej Alatoo, Karabatkak, in subalpine meadow, on Phlomis oreophila, 3200 m a.s.1., August 1., 1971, leg. K. Kalamees (TAA 79647).

Description. Cap hygrophanous, translucently striate at margin, nearly white and convex when young, pale beige and centrally depressed finally, with enrolled margin, $0.2-0.5 \mathrm{~cm}$. Gills whitish, distant, decurrent, not reduced. Stem white, all over densely white pubescent-hairy, base swollen and strigose, $1-1.5 \times 0.1 \mathrm{~cm}$. Smell and taste not distinctive. Spores broadly ellipsoid, smooth, inamyloid, $(6-) 7-8 \times 4-5 \mu \mathrm{m} . \mathrm{Q}=(1,4-) 1.5-1.7$. Hymenial cystidia absent. Basidia 4-spored, 25-50 $\times 5-7 \mu \mathrm{m}$. Caulocystidia at base of stem narrowly conical, thin-walled, occasionally with septae, 35-100 (-129) $\times 5-6.5 \times 2-2.5 \mu \mathrm{m}$. Pileocystidia absent. Pileipellis a layer of branched and slightly inflated hyphae, 


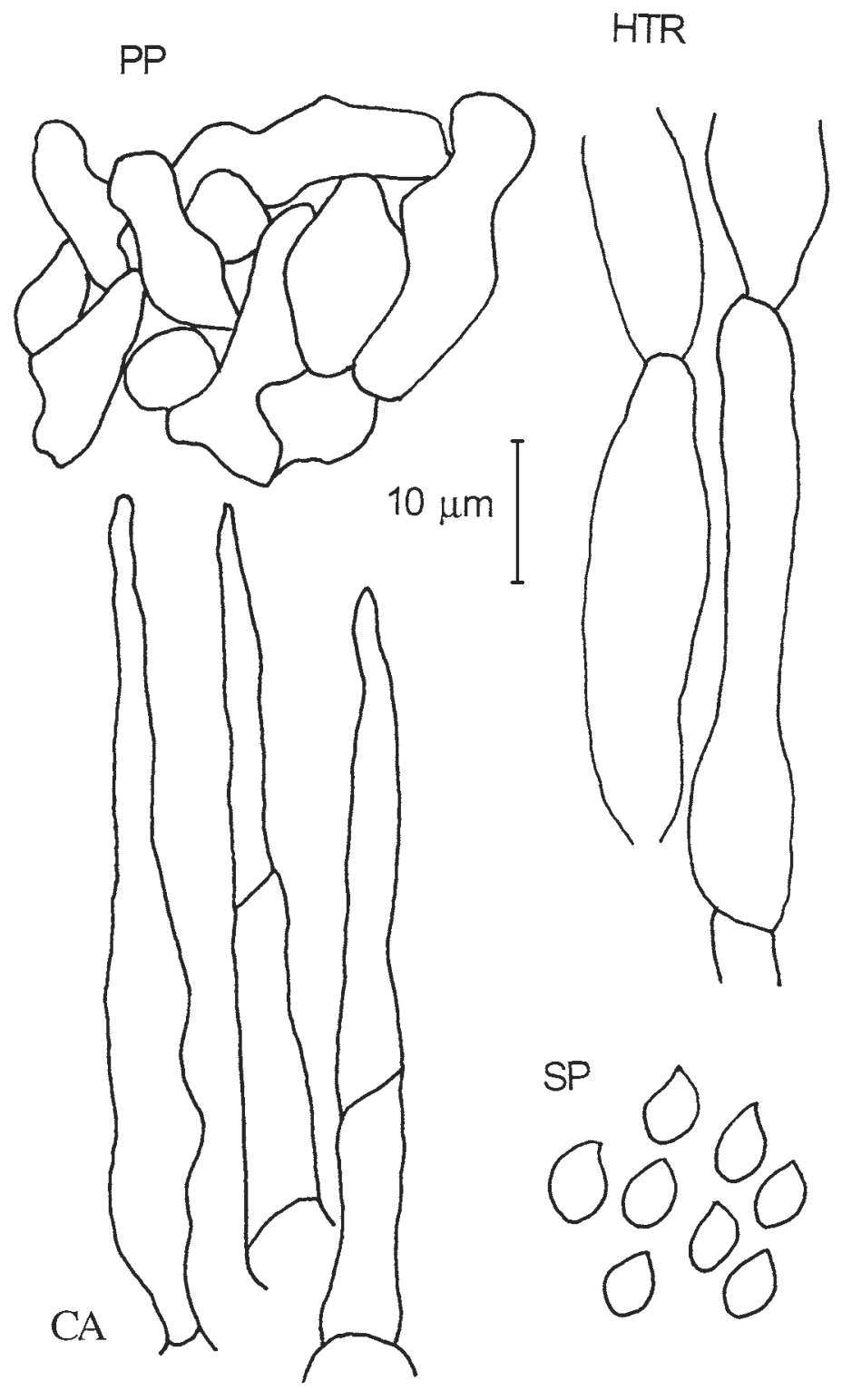

Fig. 1. Hemimycena phlomisii Kalamees: PP - hyphae of pileipellis, HTR - hyphae of hymenophoral trama, CA - caulocystidia, $\mathrm{SP}-$ basidiospores. $\mathrm{Bar}=10 \mu \mathrm{m}$.

7-19 $\mu \mathrm{m}$ wide. All hyphae without clamps.

Habitat and distribution. Very common in subalpine and alpine meadows on decayed remnants of Phlomis oreophila in Tyan'-Shan' Mt. 
Taxonomic notes. Characteristics of the species are: very small white fruit body with a densely hairy stem, small, broadly ellipsoid spores, thin-walled caulocystidia, and growing on Phlomis oreophila (Lamiaceae). H. epichloe (Kühner) Singer differs by having reduced gills, large, cylindric spores (8-12 × 3-4.5 $\mu \mathrm{m}$, cf. Antonin et Noordeloos 2004), and by growing on Carex sp. and Scirpus sp.

\section{Inocybe giacomi Favre}

Description. Cap yellowish brown, dark fibrillose, campanulate-umbonate, slightly squamulose at centre, up to $4 \mathrm{~cm}$. Gills whitish to pale brown. Stem pale pinkish brown when young, fibrillose, up to $5 \times 0.5 \mathrm{~cm}$. Spores 4-5-angular, with few small nodules, $(8-) 10-12 \times 4.5-6.5 \mu \mathrm{m}$. Cheilocystidia inflated, ventricose-lageniform, few crested, 40-60 × 15-20 $\mu \mathrm{m}$. Pleurocystidia similar to cheilocystidia.

Habitat, distribution and specimen examined. Russia, Altaj Mt., Karatyurek, in subalpine shrubs, 2200 m a.s.1., July 26., 1969 (TAA 77908); rare.

Taxonomic note. Characteristics of the species are the whitish gills and large angular spores with few nodules or without knobs.

Note on distribution. Rather common arctic-alpine species in Eurasia, also in Svalbard and Greenland (Senn-Irlet et al. 1990; Karatygin et al. 1999).

\section{Lactarius brunneoviolaceus M.P. Christ.}

\section{Syn. L. uvidus sensu Kühner; L. robertianus Bon}

Description. Fruit body turning violet. Cap dark violaceous brown, viscid, acutely umbonate, up to $3 \mathrm{~cm}$. Gills whitish to pale yellowish, adnate with tooth. Stem white, up to $2 \times 0.8 \mathrm{~cm}$. Milk white, turning violet. Smell specific (like cedar-oil when cut). Taste rather mild. Spores subglobose, amyloid, with low warts and few connections between them, 10-10.5 × 7.5-8 $\mu \mathrm{m}$.

Habitat, distribution and specimen examined. Russia, Altaj Mt., Karatyurek, in subalpine shrubs, 2200 m a.s.1., July 26., 1969 (TAA 77912, 77913); rare.

Taxonomic notes. Characteristics of the species are dark violaceous brown cap, whitish gills and specific smell. The species resembles L. pseudouvidus Kühner having paler greyish buff cap, warm buff gills and densely reticulate spores.

Note on distribution. Uncommon in arctic-alpine shrubs and meadows, with Dryas octopetala, Betula spp., Juniperus spp., in Eurasia, Spitsbergen, Greenland, Svalbard, the Faroes, Iceland (Heilmann-Clausen et al. 1998; Knudsen et Mukhin 1996; Karatygin et al. 1999).

\section{Lactarius dryadophilus Kühner}

Description. Fruit body large and robust, very pale coloured, turning violet on exposure. Cap whitish, pale yellowish, glutinous, margin involute when young, nearly smooth when adult, up to $10 \mathrm{~cm}$. Gills pale cream, broadly adnate, subdistant, often forked. Stem concolorous with cap, yellowish grooved, viscid, short and thick, up to $4 \times 2 \mathrm{~cm}$. Latex watery-white, turning violet. Smell rather strong, specific (as by L. repraesentaneus). Taste mild. Spores subglobose, amyloid, with low warts and few connections between them, 9-11 × 8-9.5 $\mu \mathrm{m}$.

Habitat, distribution and specimen examined. Russia, Altaj Mt., Karatyurek, in subalpine shrubs, 2200 m a.s.1., July 26., 1969 (TAA 77911); common.

Taxonomic notes. Characteristics of the species are: robust and large fruit-body, whitish, glutinous cap, short viscid grooved stem and strong specific smell. Similar are L. salicis-reticulatae Kühner having a slender and fragile fruit-body, smooth cap margin when young and not pitted stem, 
as well as $L$. repraesentaneus Kühner with chrome-yellow, densely bearded cap.

Note on distribution. Common in arctic-alpine shrubs and meadows with Dryas spp., Betula spp., Salix spp., Juniperus spp. in Eurasia and Greenland (Heilmann-Clausen et al. 1998; Karatygin et al. 1999).

Melanoleuca cognata (Fr.) Konrad \& Maubl. s.l.

Description. Cap light brown, viscid, convex-umbonate, up to $7 \mathrm{~cm}$. Gills emarginate, pale yellowish. Stem pale brownish, fibrillose, slender, swollen at base, up to $11 \times 0.9$ (base to 1.2 ) $\mathrm{cm}$. Smell aromatic. Hymenial cystidia ventricose, fusoid-lageniform, without septae, few crested. Spores ellipsoid, slightly verrucose, amyloid, 8.5-10 × 5-6 $\mu \mathrm{m}$.

Habitat, distribution and specimen examined. Russia, Altaj Mt., Karatyurek, on alpine meadows, $2200 \mathrm{~m}$ a.s.1., July 26., 1969 (TAA 77909); rare.

Note on distribution. Common mountain taxon in Europe (Kühner, 1978; Bon 1995).

Rickenella fibula (Bull. : Fr.) Raithelhub.

Habitat, distribution and specimen examined. Russia, Altaj Mt., Karatyurek, in the alpine zone in rocky places amongst mosses, 2800 m a.s.1., July 28., 1969 (TAA 77916); rare.

Note on distribution. Common in Eurasia in forests and in meadows amongst mosses, up to the alpine belt.

Rugosomyces caucasicus (Singer) Kalamees

Syn. Tricholoma chrysenteron ssp. alpestre sensu Vasil'eva 1939; Calocybe alpestris sensu Singer 1943.

Habitat, distribution and specimen examined. Russia, Altaj Mt., Karatyurek, $1800 \mathrm{~m}$ a.s.1., July 25., 1969 (TAA 77880) (see Kalamees 2004).

Note on distribution. Rare in subalpine shrubs and on alpine meadows in Caucasus Mt. (Vasil'eva 1939; Singer 1943) and Altaj Mt. (Kalamees 2004).

\section{REFERENCES}

Antonín, V. \& Noordeloos, M.E. 2004. A monograph of the genera Hemimycena, Delicatula, Fayodia, Gamundia, Myxomphalia, Resinomycena, Rickenella and Xeromphalina (Tribus Mycenae sensu Singer. Mycena excluded) in Europa. - IHW Verlag, Eching.

Bon, M. 1995. Die Grosspilzflora in Europa 2. Tricholomataceae 1. - IHW Verlag, Eching.

Bon, M. 1999. Flore mycologique d'Europe 5. Les Collybio-Marasmioides et ressemblants. - Docums mycol. Mem. Hors. Ser. 5: 1-171.

Brandrud, T.E., Lindström, H., Marklund, H., Melot, J. \& Muskos, S. 1994. Cortinarius flora photographica, Vol. 3. - Cortinarius HB, Matfors.

Butcher, J. 1992. The Cambridge handbook copy-editing for editors, authors, publishers, ed. 3. - Cambridge.

Eljchibayev, A.A. 1969. On macromycetes flora of Central Tienshan. - Micol. Fitopatol. 3:38-43. (In Russian.) 
Gulden, G., Jenssen, K.M. \& Stordal, J. 1985. Arctic and alpine fungi - 1. -Soppkonsulenten, Oslo.

Heilmann-Clausen J., Verbeken A. \& Vesterholt J. 1998. Fungi of Northern Europe. Vol. 2: The genus Lactarius. - Svampetryk, Copenhagen.

Horak, E. 2005. Röhrlinge und Blätterpilze in Europa. 6., völlig neu bearbeitete Auflage fussend auf Moser, 5. Auflage (1983): Kleine Kryptogamenflora, Band II, Teil b2. Gustav Fischer Verlag. - Elsevier, München.

Kalamees, K. 2004. Palearctic Lyophyllaceae (Tricholomatales) in northern and eastern Europe and Asia. - Scr. mycol. 18: 1-135.

Karatygin, E.L., Nezdoiminogo, E.L., Novozhilov, Yu.K. \& Zhurbenko, M.P. 1999. Russian arctic fungi. Check-list. - St. Petersburg.

Knudsen, H. \& Mukhin V.A. 1998. The arctic-alpine agaric element in the Polar Urals and Yamal, Western Siberia. - In: Mukhin, V.A. \& Knudsen, H. (eds), Arctic and alpine mycology 5. Proceedings of the Fifth International Symposium on Arcto-Alpine Mycology (Labytnangi, Russia, August 15-27, 1996). Yekaterinburg Publishers, Yekaterinburg, pp. 152-162.

Kühner, R. 1978. Agaricales de la zone Alpine. Genre Melanoleuca Pat. - Bull. mens. Soc. Linn. Lyon 47: 12-52.

Moser, M. 1983. Die Röhrlinge und Blätterpilze (Polyporales, Boletales, Agaricales, Russulales). (Gams, H. Kleine Kryptogamenflora IIb/2. Basidiomyceten 2. 5. Aufl) - Fischer, Jena.

Senn-Irlet, B., Jenssen, K.M. \& Gulden, G. 1990. Arctic and alpine fungi - 3. - Soppkonsulenten, Oslo.

Singer, R. 1943. Das System der Agaricales III. - Ann. Mycol. 41: 1-189.

Singer, R. 1962. Diagnoses fungorum novorum Agaricalium. II. - Sydowia 15: 45-83.

Singer, R. 1978. Keys for the identification of the species of Agaricales. I. - Sydowia 30: 192.

Vasil'eva. L.N. 1939. Le champignons de la reserve caucasienne. - Uchen. ZAP. Kazansk. Gosud. Univ. Ul'yanov-Lenina 99 :3-66. 